\title{
Student chapters: effective dissemination networks for informal optics and photonics education
}

Dirk Fabian, Nathalie Vermeulen, Sara Van Overmeire

Dirk Fabian, Nathalie Vermeulen, Sara Van Overmeire, "Student chapters: effective dissemination networks for informal optics and photonics education," Proc. SPIE 9666, 11th Education and Training in Optics and Photonics Conference, 96660A (5 June 2009); doi: 10.1117/12.2207947

SPIE Event: Eleventh International Topical Meeting on Education and Training in Optics and Photonics, 2009, St. Asaph, United Kingdom 


\title{
Student chapters: effective dissemination networks for informal optics and photonics education
}

\author{
Dirk Fabian \\ SPIE - The International Society for Optics \& Photonics \\ $100020^{\text {th }}$ St., Bellingham, WA 98225, USA \\ dirkf@spie.org \\ Nathalie Vermeulen \& Sara Van Overmeire \\ Vrije Universiteit Brussel, Department of Applied Physics and Photonics \\ IR-TONA Pleinlaan 21050 Brussel BELGIUM \\ nvermeul@vub.ac.be, svoverme@vub.ac.be
}

\begin{abstract}
Professional societies sponsor student chapters in order to foster scholarship and training in photonics at the college and graduate level, but they are also an excellent resource for disseminating photonics knowledge to pre-college students and teachers. Starting in 2006, we tracked the involvement of SPIE student chapter volunteers in informal pre-college education settings. Chapter students reached 2800,4900 and 11800 pre-college students respectively from 2006-2008 with some form of informal instruction in optics and photonics. As a case study, the EduKit, a self-contained instruction module featuring refractive and diffractive micro-optics developed by the European Network of Excellence on Micro-Optics (NEMO), was disseminated through student chapters in Argentina, Belgium, Canada, China, Colombia, India, Latvia, Mexico, Peru, Russia, Singapore, South Africa, and the United States. We tracked the movement of this material through the network, up to the student-teacher feedback stage. The student chapter network provided rapid dissemination of the material, translation of the material into the local language, and leveraged existing chapter contacts in schools to provide an audience. We describe the student chapter network and its impact on the development of the EduKit teaching module.
\end{abstract}

Keywords: Education, informal science, networks, student organization, outreach, language

\section{Introduction}

Engaging pre-college students in optics and photonics education is of vital importance to developing an educated research and work force that can conduct the exploration of light-based phenomena and technology. Numerous practical curriculum modules, after school experiments, and demonstrations designed to reach pre-college students have been detailed in the ETOP conference proceedings, but the developers of these programs can be stalled at the next step - getting the material into the hands of capable teachers that understand some optics and have significant student contact time. Various teacher networks, such as MESA ${ }^{1}$ or Project PHOTON $^{2}$ seek to address this issue with teacher training programs, backed up by administrative and networking support. However, these teacher development and linking programs are not present in all communities, and are often absent in developing countries.

How can good materials find the wider audience and support that they need? How can like-minded people interested in this subject work together in a way that helps expose more pre-college students to optics and photonics educational materials? The purpose of this paper is to describe one way that education researchers and curriculum developers in optics and photonics can reach a wider audience of pre-college students world-

Eleventh International Topical Meeting on Education and Training in Optics and

Photonics, edited by K. Alan Shore, Deb Kane, Proc. of SPIE Vol. 9666, 96660A

(c) 2009 SPIE, OSA, IEEE, ICO · doi: 10.1117/12.2207947 
wide in a way that responds to local needs and conditions. In section 2, we will describe the SPIE network of student chapters, the characteristics that make them effective, and their involvement in outreach to date. In section 3, we will examine the EduKit project as an example of the use of this network for dissemination of educational materials.

\section{Growth of the SPIE Student Chapter network}

A student chapter is a campus organization of students who receive funding and networking support from a national or international professional organization. Student membership and chapter membership with SPIEthe International Society for Optics and Photonics - is targeted at undergraduate and graduate students involved in an optics and photonics program, though middle and high school; community college students are involved as well.

Student chapters have been a part of SPIE since the first chapter at California Polytechnic University at San Luis Obispo was founded in the mid-1990s. This chapter languished and the chapter program as a whole grew slowly through the late 1990s, attracting a total of only 5 chapters by the end of 2000 . This first group exhibited a wide diversity in education goals - optics research powerhouse University of Central Florida, an after-school program at a Columbia, Missouri area public high school, and the technician-oriented Three Rivers Community College; and geography - with Tsinghua University (China) and the Warsaw University of Technology (Poland). While this diversity speaks to the wide impact of photonics, it also made it difficult to provide a coherent set of benefits to chapters that would satisfy all members.

In 2002, the chapter development effort received dedicated staff support and financial resources to expand. In two years, this modest investment of resources produced a strong return in program interest and new chapter formation. In 2004, SPIE launched a successful three-year student pipeline initiative as part of its strategic plan that resulted in strong growth in student membership and student chapters, as well as programs for non-member students. The goal of the initiative was to increase the visibility of optics while feeding the pipeline of students into optics/photonics education and careers. The initiative was completed at the end of 2006, and the program has continued as part of ongoing SPIE operations since then. Momentum from the program has resulted in continued growth of student programs, student members (Figure 1), student chapters (Figure 2), and the recognition of the need for an Early Career Professional (ECP) program to help support new professionals during their post-terminal degree transition years.

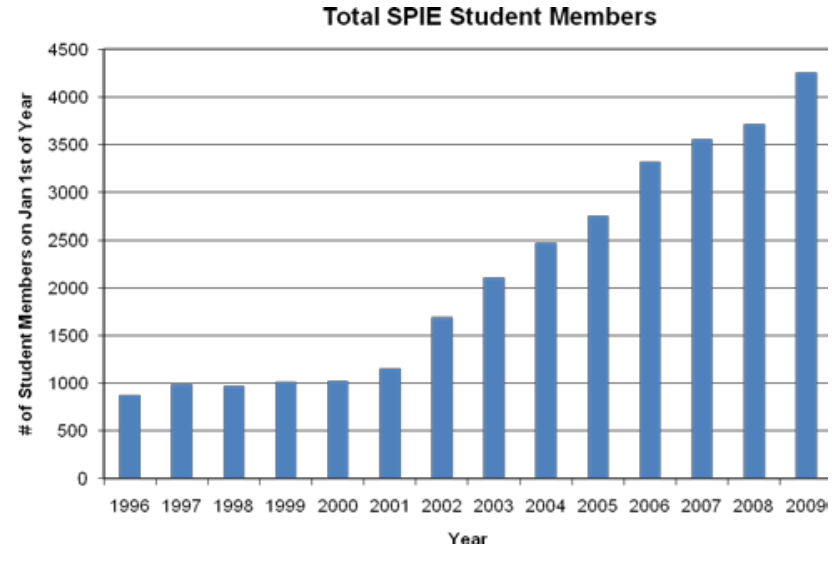

Figure 1 - Total student membership in SPIE over time

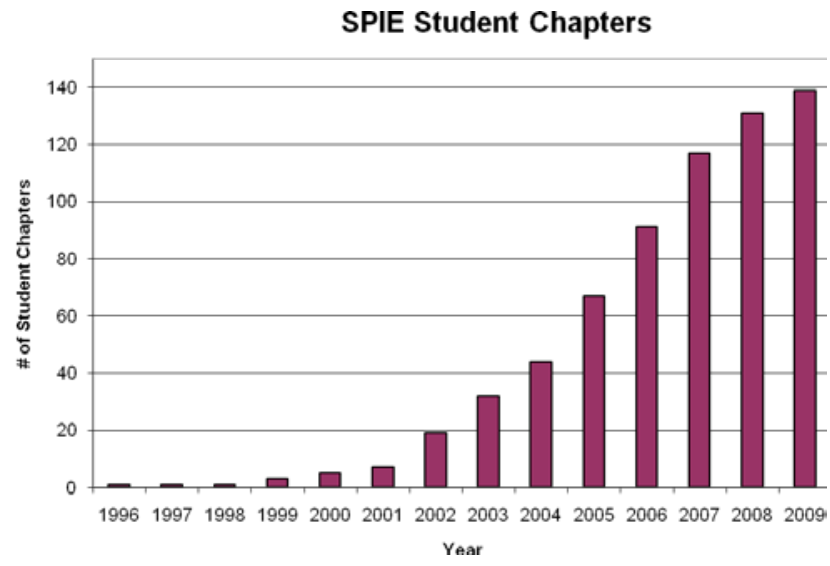

Figure 2 - Growth of SPIE student chapters over time. 145 chapters are anticipated by year-end 2009 
Since the initiative launch in 2004, SPIE Student Membership has grown $72 \%$ (to 4,260) and Student Members now make up one quarter of SPIE's total membership. Student chapters now number 139. While not all chapters are active at all times, roughly $85 \%$ of chapters participate with SPIE for at least one of their chapter benefits in the course of a year. Inactive chapters are removed from the ranks after a one year review process.

\subsection{Student chapter benefits}

Student Chapters enjoy a wide variety of support from the Society - a yearly activity grant that scales with the size of the chapter, an officer travel grant to attend an SPIE meeting, a workshop on leadership and professional development, support for a Visiting Lecturer to speak at their university or event, free books, and educational outreach materials such as the Hands-on-Optics kits and informational posters. Through the organization of chapter activities, students also become familiar with SPIE programs and opportunities as a whole: submitting papers, serving on governance committees, and networking with current society leadership. Non-member students receive support through our Lunch with the Experts events and professional development speakers at major SPIE meetings. Quarterly student newsletters and networking through Facebook (an online social networking forum) round out the program.

All three professional societies focused on optics and photonics (SPIE, OSA, IEEE-Photonics) support student chapter programs as part of their educational missions. Students at numerous schools have recognized this overlap, the availability of resources through the various society programs, and have formed joint chapters of the three societies. Leveraging resources across the three societies has allowed chapters to pursue ambitious outreach programs.

\subsection{Chapter structure and access}

The return on the program is that SPIE has gained a large number of young advocates and contacts in universities around the world. SPIE maintains contact with an ever-changing group of student leaders and chapter advisors. Chapters are typically organized with an elected student executive group (President, VicePresident, Secretary, and Treasurer) and a faculty member as chapter advisor. Most chapters observe a one year term limit for each student position. While small chapters sometimes have trouble filling all positions, large chapters often add positions to coordinate specific functions like membership rosters, web management, speaker selection, or outreach efforts. The chapter structure is flexible based on the needs of the group. Currently, 645 students and faculty hold positions within chapters, and this number has grown steadily with the chapter growth. This core leadership group of students and faculty within the chapter program is in more direct contact with SPIE staff than the general membership.

Accessing this network of students and advisors is done by going to the student chapter webpage: http://spie.org/studentchapters or sending an e-mail to students@spie.org with your message and target audience request. Individual chapters are also encouraged to maintain their own websites with expanded program information and contact information - links can be found on the individual chapter pages. The main page will soon be upgraded to provide better geographic information about chapters and more direct links to contact chapter officers via the Profiles feature on SPIE.org.

\subsection{Distribution of chapters: geography, language, and economy}

Regional development of chapters followed the historical relationships developed through the larger SPIE organization. Strong connections in Eastern Europe led to rapid growth of chapters in Poland, Ukraine, and Russia early in the program. Outreach by 2005 president Malgorzata Kujawinska brought connections and chapters in India. Subsequent presidents have made efforts in China and Latin America to good effect.

The wide geographic distribution of chapters has been particularly significant in providing one of the unique strengths of the program: multi-lingual ability. Although the lingua franca of science is English, outreach instruction in the local community must by nature take place in the local language. Student chapter members 
are the best equipped to manage the translation between any instructional materials they might receive, their common language of instruction, and the dominant language of the region. In all, SPIE chapters work in 22 different languages.

SPIE membership costs are reduced for individuals residing in countries that are eligible for Special Economic Consideration, as selected by the World Bank ${ }^{3}$. Seventy-seven SPIE student chapters exist in countries eligible for this rate, or $55 \%$ of the total chapters. While this simple binary metric cannot reflect the diversity of the economic conditions in the various countries, it is a useful indicator.

\begin{tabular}{|lcl|}
\hline Country & Number of Chapters & Language \\
\hline Argentina & 2 & Spanish \\
\hline Armenia & 1 & Armenian, Russian \\
\hline Belgium & 1 & Dutch, French \\
\hline Brazil & 1 & Portuguese \\
\hline Canada & 5 & English, French \\
\hline China & 18 & Chinese (Mandarin 17, Cantonese 1) \\
\hline Colombia & 3 & Spanish \\
\hline Germany & 1 & German \\
\hline India & 9 & Hindi, Telegu, Malayalam, Bengali \\
\hline Ireland & 1 & English \\
\hline Japan & 2 & Japanese \\
\hline Latvia & 1 & Latvian \\
\hline Malaysia & 1 & Malay \\
\hline Mexico & 7 & Spanish \\
\hline Peru & 1 & Spanish \\
\hline Poland & 6 & Polish \\
\hline Romania & 1 & Romanian \\
\hline Russia & 13 & Russian \\
\hline Singapore & 1 & English, Chinese \\
\hline South Africa & English \\
\hline Spain & 1 & Spanish \\
\hline Taiwan & 1 & Chinese (Mandarin) \\
\hline Thailand & 4 & Thai \\
\hline Turkey & 1 & Turkish \\
\hline Ukraine & 1 & Ukrainian \\
\hline United Kingdom & 8 & English \\
\hline United States & 2 & English \\
\hline & 44 & \\
\hline & & 13 \\
\hline
\end{tabular}

Table 1 - Distribution of student chapters by country and primary language 


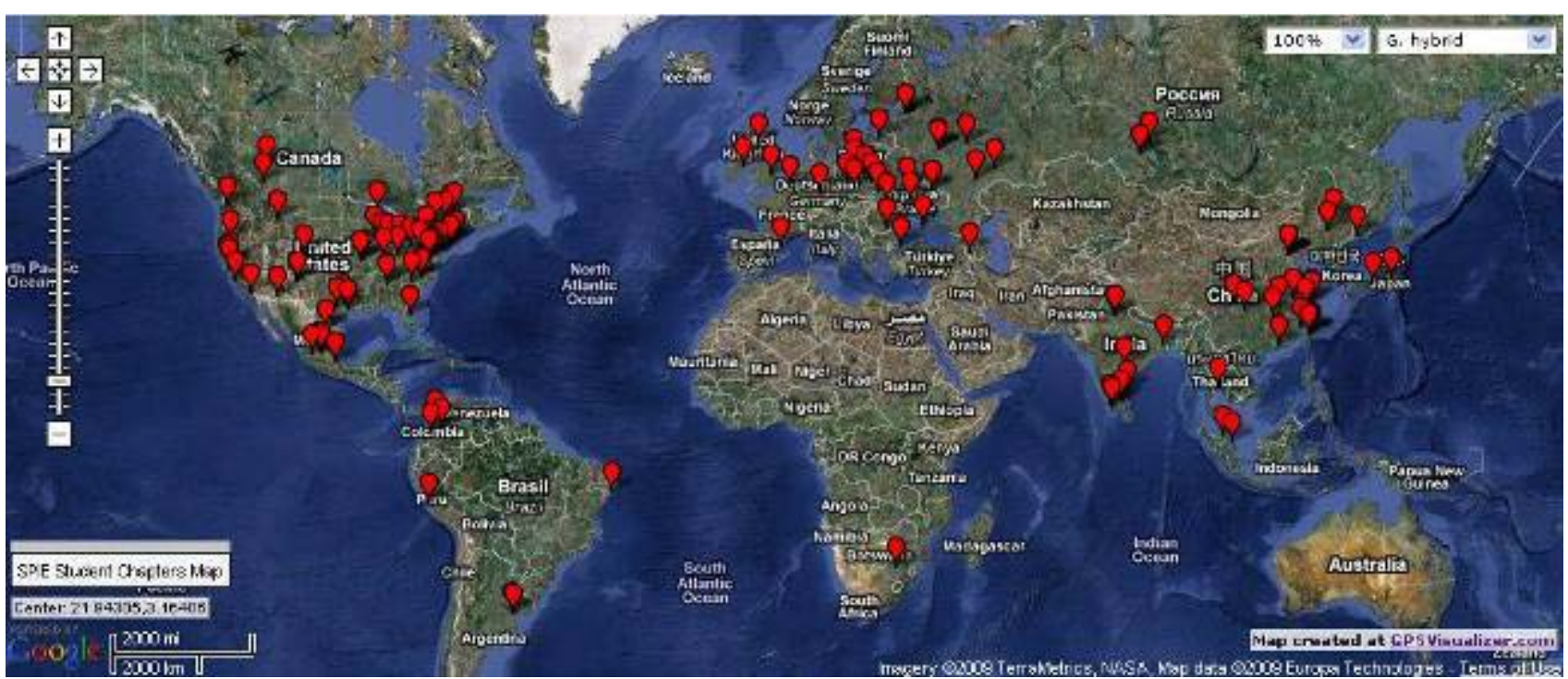

Figure 3 - Distribution of 139 SPIE Student Chapters throughout the world as of mid-June, 2009

\subsection{Sustainability and development of chapters at different educational levels}

Chapters naturally wax and wane in their activity over the course of their existence. While the goal is that once started, a chapter becomes self-sustaining indefinitely, the reality can be different. In addition to the human factors of enthusiasm, connection to the community, and succession of members, external factors also play a large role in whether chapters stay active. In the last five years, experience has shown that the chapters which stay active and engaged with SPIE share certain characteristics of program size, turn-over rate, and relevance. Among them, size of the host optics program has the most direct influence on the continued viability of chapters. Larger optics programs tend to have chapters that remain active and can easily be restarted if activities lapse.

High School chapters suffer the most from these factors. High school chapters have been organized around after school programs and individual technical training classes. An engaged and active chapter advisor is a necessity since often high school students lack the self-confidence and organization to act as a group. In addition to these hurdles, students only become acquainted with the math, geometry, and physics related to optics in their $3^{\text {rd }}$ or $4^{\text {th }}$ year of education, and optics and photonics is rarely included in the pre-college curriculum. With a small number of interested students and at best one year of familiarity with the chapter and the subject material, pre-college chapters rarely remain active from year to year. The SPIE program offerings themselves do not lend themselves well to high school chapters, the primary benefits being related to scientific conference attendance and career development. High school groups interested in optics \& photonics are more successful in partnership with an active university chapter, using SPIE resources such as the optics posters as a supplemental resource.

Community college programs face similar issues of turn-over and relevance that high school chapters face. The topics of modern physics and the interaction of light with matter are typically taught as a second year university course in the United States, giving students little time to become versed in the material. Focused optics programs like that at Three Rivers Community College overcome some of this by starting students on optics content early, with hands-on experimentation techniques. Because of the rapid turnover of students, strong faculty leadership is essential to sustaining interest in the chapter in this environment.

Programs consisting primarily of undergraduates have a wider window for student involvement (less turnover) and relevance than community college programs. Four year undergraduate programs allow students significant time to become familiar with optics and photonics content. In addition, students have the time to 
become familiar with the chapter structure, enabling them to develop outreach efforts in their community. Undergraduates can often act as content experts for pre-college students or teachers and welcome the chance to develop their teaching techniques.

Most SPIE chapters consist of both undergraduate and graduate students, with graduate students tending to dominate the chapter leadership due to their optics focus, time availability, and the relevance of optics in their lives. Chapters that manage to integrate their programs so that undergraduate and graduate students work together on projects can be quite successful. Developing activities and systems that engage both the graduate and undergraduate students in chapter activities is quite challenging, and chapters have cited "engaging undergraduates in chapter activities" in surveys of the biggest challenges facing chapter leaders.

\subsection{Variety in Outreach by chapters}

When chapters have strong leadership, motivation, and access to resources, they can reach large numbers of pre-college students. Not surprisingly, the variety of outreach activities that student chapters conceive, design, and execute is quite significant. Appendix A contains a detailed listing of chapter outreach activities for the most complete years of the survey, 2006, 2007 and 2008. The following list calls out unique projects that have had a wide impact or exhibit a new pathway for reaching students with optics content:

- The Centro de Investigaciones en Óptica Student Chapter obtained a monthly spot on children's public television program TV4Ninos, which is broadcast by TV Qu4tro, a statewide broadcaster with over 3 million viewers. During the spot, $\mathrm{ClO}$ members perform different experiments in real time in order to explain basic scientific concepts.

- The Instituto Nacional de Astrofísica, Óptica y Electrónica Student Chapter created two workshops for the 2nd International Reading Fair,

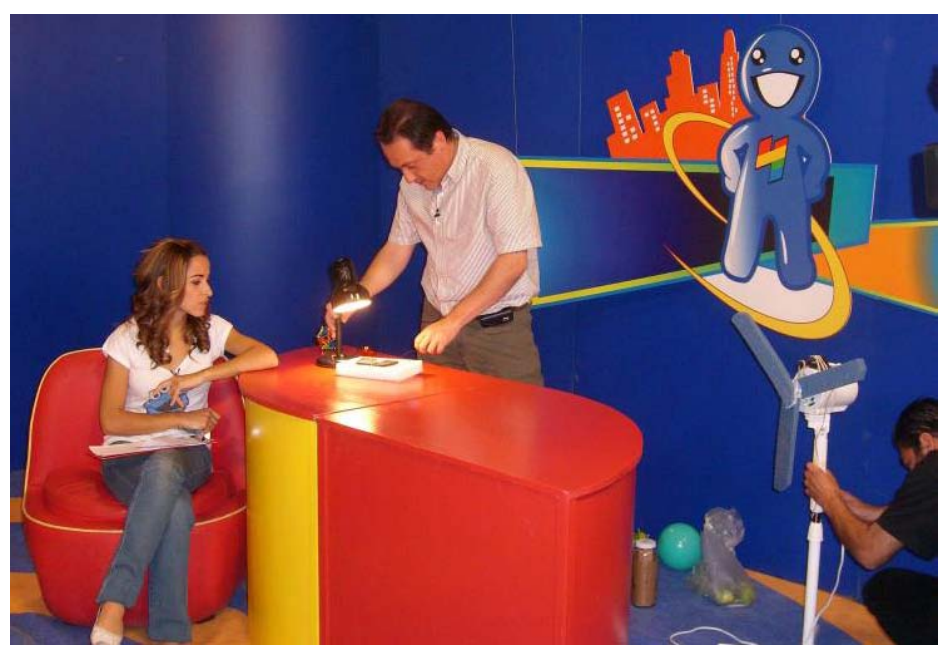

Figure $4-\mathrm{ClO}$ students and faculty demonstrate how solar panels work in their public television program an event attended by 20,000 school children. The workshops involved building periscopes and kaleidoscopes in order to illustrate basic optics principles. Roughly 1,000 children built periscopes and 900 children built kaleidoscopes. Additionally, the chapter brought telescopes to downtown Mexico City for a total lunar eclipse so that people could observe the phenomenon more closely. Roughly 1,000 people participated in this activity.

- The International School of Photonics Student Chapter held their third annual Optics Fair on November 28-29. More than $1400 \mathrm{~K}-12$ students attended the fair, where scientific experiments tailored to their age levels were demonstrated.

- The Nicholas Copernicus Univ. Student Chapter took part in the $8^{\text {th }}$ Annual Festival of Art and Science, a city-wide science outreach effort. They designed a workshop where they presented physical experiments describing interesting natural phenomena. Their event drew almost 1,000 visitors over the course of three days. 
- The Stanford Student Chapter hosted an online optics-themed photography contest for $6^{\text {th }}-12^{\text {th }}$ graders, receiving more than 50 entries. They also hosted a field trip, called Girls Go Tech 2008, for $\mathrm{K}-3^{\text {rd }}$ grade girl scouts. They took the scouts to the Chabot Space and Science Center in Oakland where they did a number of hands-on optics activities with them. They expanded content for the Stanford OSA/SPIE Student Chapter YouTube channel, which features videos covering their educational outreach, academic, and networking events.

\subsection{Measuring Outreach}

On the first of each month, 10-15 chapter reports are due to SPIE covering the annual activities for the chapter. All chapters are expected to provide an annual report of activities whether or not they have received funding in that year. In practice, we receive reports from about $80 \%$ of all chapters. Staff provides feedback on the reports, uploads them to the chapter web page for record keeping and dissemination, and notes if there have been any outreach activities performed by the group. If there have been outreach activities during the year, we attempt to determine how many people participated in this activity. Some chapters provide their own estimates of the numbers of students at their events, and this is explicitly part of the chapter report guidelines. In cases where no numbers are provided, we either query the chapter leadership or attempt to estimate the number of participating pre-college students from any pictures of the outreach activity. While counting the number of people in the pictures is crude, it does provide a quick, rough number. Especially notable or well-attended outreach activities are highlighted in the quarterly student newsletter: Wavefront, which can be accessed on the web ${ }^{4}$.

In the three years that Outreach efforts have been tracked, 2006, 2007, and 2008, SPIE student chapters reached 2800, 4900 and 11800 students with some form of optics education. Tracking was incomplete in 2006 and has not yet completed for the 2009 school year. Because of the wide variety of outreach projects performed and the uncertainty in the numbers of participants and duration of the events, we do not attempt to count contact hours per student for the events. Certainly, the type of contact varies for each event - some pre-college students take part in multi-day summer programs led by chapters, while others are involved in a series of demonstrations lasting for just an hour. This is especially apparent in 2008, when numerous student chapters undertook exceptionally large outreach events. Sophisticated presentations, such as the Vrije Universiteit Chapter's "Fascination of Light" Science show, brought large numbers of pre-college students and teachers into contact with optics and photonics concepts. Other chapters, like the University of Arizona, worked on a week-long optical sciences camp for high school students. While the numbers of students reached are vastly different, the total contact hours for both projects would likely be approximately equal. Despite the difficulty in finding a way to track these events on a level that recognizes their differences, we believe that even a basic amount of counting helps quantify the impact of student chapters in their communities.

\subsection{Face-to-face: Catalyzing the effectiveness of student chapter programs}

While online networks can provide the communications infrastructure for educational outreach, face to face meetings have been essential in bringing projects to a wider audience. Annually, SPIE hosts the Student Chapter Leadership Workshop as part of the Optics \& Photonics conference in San Diego. This workshop provides funding to bring a representative from all student chapters in good standing to San Diego for a day and a half program of professional development and networking. Since 2004, the Leadership workshop has hosted 50-90 chapter representatives and an additional 30-50 chapter students and veteran leaders each year (80 attendees ('05), 110 attendees ('06), 125 attendees ('07), 135 attendees ('08)).

This face to face meeting has been used effectively to provide both materials and outreach training through optional free courses. The Hands on Optics (HOO) program $^{5,6}$, a partnership of SPIE, OSA, and the National Optical Astronomy Observatory (NOAO), has hosted training programs for its optics modules at both the Optics \& Photonics conference and Photonics West since 2006. In the last 3 years, the training program has focused on the Terrific Telescopes mini-kit ${ }^{7}$, a portable version of the Magnificent Magnifications module. The mini-kit provides materials and instruction for an educator to assist students in constructing a small refracting 
telescope and determine the properties of the lenses and structures that make up the telescope. The kits are roughly the size of a thick laptop computer case, and contain enough materials to make 5 telescopes.

Throughout the program, the distribution of materials widely to chapters has proven difficult and expensive using standard post and shipping methods. Providing the kits directly to the students at the conference eliminates this issue. More importantly, the training courses get student educators to become familiar with the HOO mini-kit and hopefully to embrace the inquiry-based educational techniques of the modules.

Recognizing that students have deeply rooted preconceptions of how natural phenomena like light and reflection actually work is a primary development of recent educational research and has been incorporated into the $\mathrm{HOO}$ modules thoroughly ${ }^{8}$. Outreach training lessons serve to model the teaching experience so that student educators can take it out into the pre-college environment the best techniques.

Using the resources and timing of the Leadership workshop to disseminate optics education materials is an effective way to leverage resources. No other SPIE event in the year brings together students from such a wide variety of backgrounds with specific goals like service and outreach in mind. There is a great deal of enthusiasm for quality optics demonstrations throughout the student group, with many students building their own demonstration materials and hosting outreach events. As students work with one another, they share tips and strategies for improving the events. These meetings help students become a part of the broader network of professionals working on the problem of creating effective optics and photonics curricula.

\subsection{The EduKit project}

Through a grant from the European Commission, the Network of Excellence in Micro-Optics (NEMO) designed an outreach package called the EduKit. NEMO's goal for the EduKit program is to expose students to the potential of micro-optics in science and engineering applications by distributing Edukits for free. The heart of the kit is a plastic card containing diffractive and refractive optical elements. Combined with a laser, this card can produce a large range of beam patterns, from simple splitting and grid patterns to complex images and words. In addition to the diffractive optics card and the laser, the EduKit also contains a DVD with a description of the card and a lesson handbook in the following EU languages: Dutch, German, English, Finnish, French, Italian, Polish, Spanish, and Turkish. The EduKit materials have been described in various papers for this conference ${ }^{9}$.

In summer 2008, the SPIE Student Chapter at the Vrije Universiteit Brussel took the initiative in disseminating the EduKit to 21 other SPIE Student Chapters located in Argentina, Canada, China, Colombia, India, Latvia, Mexico, Peru, Russia, Singapore, South Africa, and the United States. Again, the Student Chapter Leadership Workshop provided a venue to inform and solicit volunteers in the project, though no on-site training was provided. The plan was to get a first round of feedback on the kit by the end of 2008 so that the program can be reviewed and improvements made on the materials. The Vrije Universiteit Brussel chapter provided total of 700 EduKits to chapters for distribution in their local communities.

$\begin{array}{ll}\text { Number of pupils at Edukit activities } & 1147 \\ \text { Number of teachers at Edukit activities } & 116 \\ \text { Number of received evaluation forms } & 17\end{array}$

The evaluation forms asked for a simple response to the quality of the EduKit materials - optics and manual:

$\begin{array}{llll} & \text { Very good } & \text { Good } & \text { Sufficient } \\ \text { Manual } & 35.29 \% & 41.18 \% & 23.53 \% \\ \text { Optics } & 47.06 \% & 47.06 \% & 5.88 \%\end{array}$

It also surveyed which experiments / demonstrations from the manual were carried out by the chapters:

$\begin{array}{llllllll} & \text { Exp I } & \text { Exp II } & \text { Exp III } & \text { Exp IV } & \text { Exp V } & \text { Exp VI } & \text { Exp VII } \\ \text { Completed } & 82.35 \% & 88.24 \% & 88.24 \% & 58.82 \% & 35.29 \% & 29.41 \% & 41.18 \%\end{array}$

The challenge of the kit is integrating it into pre-college classroom instruction. Diffractive optics can be a mind-bending topic, especially for young students who are perhaps just being introduced to simple ray-tracing 
and basic geometric optics. Although teaching the principles of diffractive optics is not a primary goal of the EduKit, some understanding of the principles at work helps with the instruction and experiments contained in the kit.

Finding good ways to use the kit materials and the included lessons was the subject of the 2008 Outreach challenge that was jointly organized by SPIE and the SPIE Student Chapter at the Vrije Universiteit Brussel. Chapters participating in the first round of the kit evaluation were offered the chance to compete for $\$ 2000$ in awards by producing short video demonstrations of basic principles and lessons that are possible with the kit. For the competition, videos were uploaded to the SciVee.tv website and judged by a panel of science education experts. The overall goal was to produce a supplement of materials that can expand the accessibility of the kit - essentially providing a quick start guide for teachers that may not have the benefit of on-site training. The challenge received three video lesson submissions which currently can be found on the SciVee.tv website, but will be made accessible through a more open video sharing site like YouTube or Vimeo.

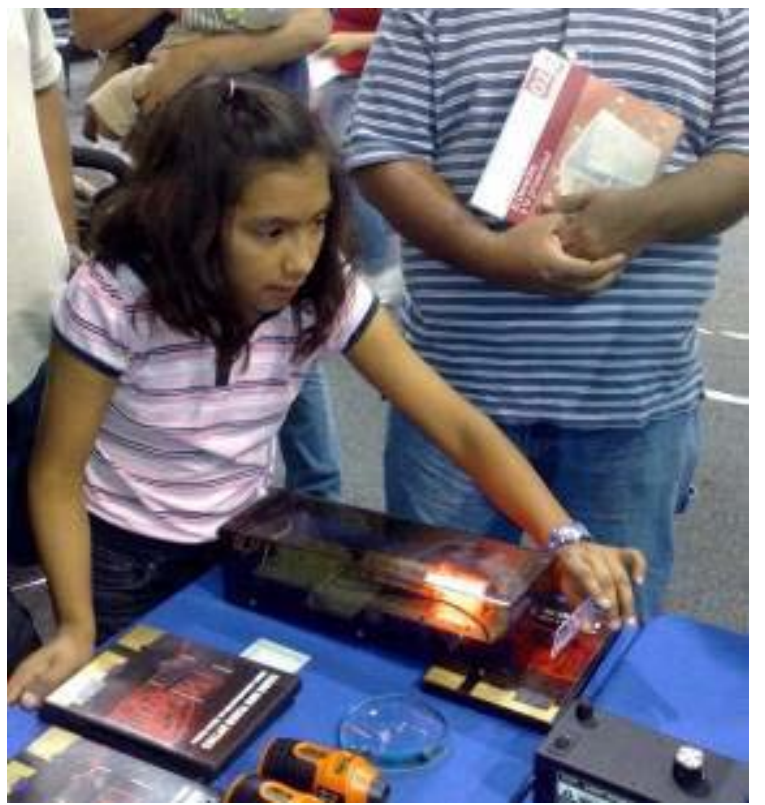

Figure $4 \mathrm{a}-$ Student manipulating the diffractive optics card

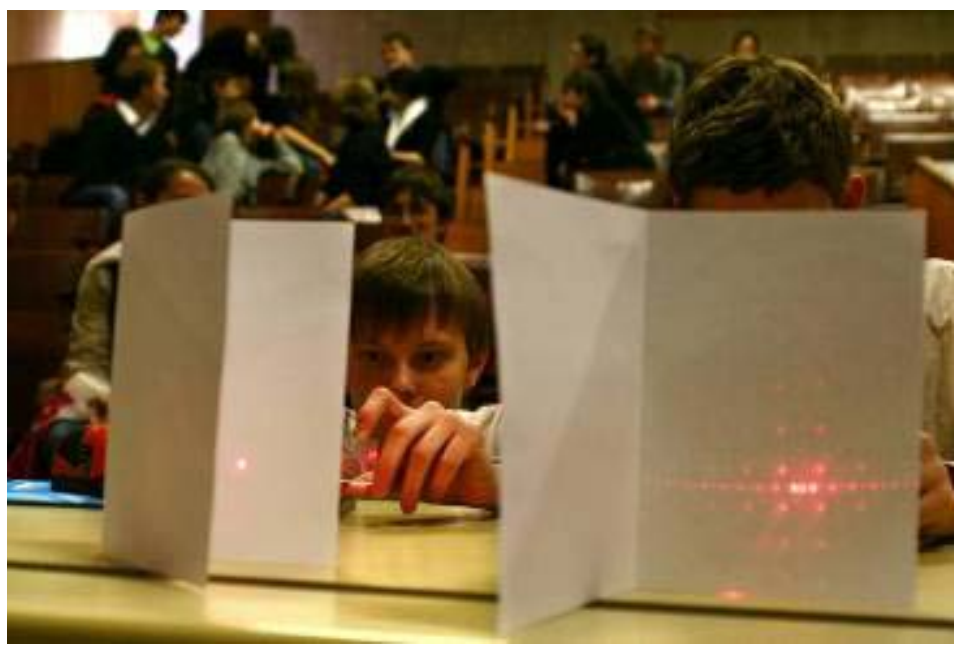

Figure $4 b-$ Various beam shapes are possible with the card

\subsection{Conclusion - Dissemination using the SPIE Student Chapter network}

The SPIE Student Chapter network proved effective in distributing both the EduKit material and collecting feedback from users. The general strengths of the network are the rapid dissemination of information and material via the leadership workshop, translation of the material into the local language when needed, and leveraging existing chapter contacts in schools to provide an audience. The importance of this last point cannot be over-emphasized. Many Student Chapters already have local connections with teachers from previous outreach contacts so a new network need not be established to test new materials. As evidence of the effectiveness of the network, dissemination of the EduKit began in mid-August 2008 at the Leadership Workshop and had reached 1147 students in the span of one academic semester.

Improvements to the system are planned primarily in two areas: group communications and post-event information sharing. Group communications for the EduKit project was still handled primarily through email, even though we used socially-based sites like SciVee.tv to store the final outreach projects. Group communications were not self-service and the interaction among chapters involved in the project was 
minimal. Helping students organize and providing the tools they need to communicate about relevant topics is a primary goal of the SPIE student program. Some tools have worked well for group collaborative communications; for example, the SPIE Student Facebook group was growing numbers (587 members) and allowed threaded discussions and information sharing. Unfortunately, changes in the Facebook business model have removed much of the visibility from groups, making this tool less accessible. New collaboration and sharing tools must be found to compensate. Google sites - a wiki-based website creation tool - may provide an answer.

The post-outreach event reports are currently available in PDF format as subsections of the chapter reports stored on the individual Student Chapter pages on spie.org. However, just because they are available does not necessarily mean that they are read. Modern information sharing through a more collaborative medium like a blog or wiki dedicated to optics education could help tag and sort outreach events by size and topic. This would make it much easier for other chapters to share outreach event plans and communicate. SPIE's information collection on these outreach events could also be improved with a dedicated feedback form for recording outreach interactions. Ideally, this would ask students to estimate contact hours and key lessons from their events.

\subsection{Summary}

We have described the size, organization, and key characteristics of the SPIE Student Chapter network; a collection of 139 campus organizations supported by the Society to engage in professional development programs like outreach to pre-college students. This network of students provides needed optics and photonics teaching in their local communities and reaches a very large number of students relative to the size of the chapter program. These outreach events have the advantages of being locally based and available in the native language of the community, relevant to the needs of the community, and employ modern concepts and teaching techniques. Overall, the student chapter network serves a very wide range of cultures, languages, geographies, and socio-economic standings. This network is accessible to people working on outreach curriculum and can serve as a rapid and effective point for dissemination for material. The Student Chapter Leadership Workshop at the SPIE Optics \& Photonics conference is an effective venue from which to communicate and distribute material that chapters can use, as we demonstrate with NEMO's EduKit project. We will continue to seek more collaborative and social means for chapters to share their outreach efforts so that quality events can spread throughout the world. 


\section{References:}

1. http://www.ucop.edu/mesa/home.html

2. http://www.nebhe.org/content/view/248/190/

3. http://spie.org/x1763.xml : World Bank list

4. http://spie.org/x1732.xml : Student Newsletter

5. http://www.hands-on-optics.org/home/

6. Pompea, S. M., Johnson, A., Arthurs, E. and C. E. Walker, (2005a). "Hands-On Optics: An Educational Initiative for Exploring Light and Color in After-School Programs, Museums, and HandsOn Science Centers", Proceedings, Ninth International Topical Meeting on Education and Training in Optics and Photonics (ETOP), Marseille, France

7. Sparks, Robert T.; Pompea, S. M.; and C. E. Walker, "Using the Hands-On Optics Terrific Telescopes Kit in The International Year of Astronomy" American Astronomical Society, AAS Meeting \#212, \#59.01; Bulletin of the American Astronomical Society, Vol. 40, p.252

8. Pompea, Stephen M., Dokter , Erin F., Walker, Constance E., and Robert T. Sparks, "Using Misconceptions Research in the Design of Optics Instructional Materials and Teacher Professional Development Programs", Proceedings, Tenth International Topical Meeting on Education and Training in Optics and Photonics (ETOP), Ottawa, Canada

9. Taghizadeh, M. R., Stijns, Erik, and Hugo Thienpont, "The NEMO educational kit", Proceedings, Ninth International Topical Meeting on Education and Training in Optics and Photonics (ETOP), Marseille, France

\section{Acknowledgements:}

This project was made possible by the efforts of the Vrijie Universiteit Brussel SPIE Student Chapter and VUB staff Nathalie Debaes and Bernadette Callebaut to distribute the EduKits. Prof. Hugo Thienpont is PI and contact for the NEMO project. DF would like to thank Marie Biondolillo for the geo-coding used to create Figure 3 and for tracking the numbers of students in Chapter Outreach events in 2007 and 2008. Teddy Parker-Renga also assisted with this effort. We would like to acknowledge the EduKit videos created by the Student Chapters from Nizhny Novgorod, Cochin University of Science and Technology, and the Samara region. Thanks are also due to video judges Prof. Judy Donnelly, Dr. Marc Nantel, and Dra. Cristina Solano for providing feedback on the video submissions. 
Appendix A: List of Student Chapter Activities by Year

2006 Outreach Activities

\begin{tabular}{|c|c|c|c|c|}
\hline Chapter & Activity & $\begin{array}{l}\text { \# people } \\
\text { reached }\end{array}$ & Type & Counted (how)? \\
\hline BGSU & High school open house & 10 & HS student & est by counting ppl in pics \\
\hline Brussels & $\begin{array}{l}\text { BEST Summer School } \\
\text { NEMO Edukit proposal } \\
\text { NEMO Edukit training }\end{array}$ & $\begin{array}{l}20 \\
14 \\
10 \\
\end{array}$ & $\begin{array}{l}10 \text { adults } \\
\text { misc children } \\
\text { Teachers }\end{array}$ & $\begin{array}{l}\text { in report } \\
\text { in report } \\
\text { in report }\end{array}$ \\
\hline CUSAT & $\begin{array}{l}10 \text { day workshop for school } \\
\text { children "Physics: Scope } \\
\text { and Awareness" }\end{array}$ & 20 & Children & in report \\
\hline $\begin{array}{l}\text { Tec de } \\
\text { Monterrey }\end{array}$ & $\begin{array}{l}\text { Second Matlab workshop } \\
\text { Mood patch workshop } \\
\text { Contact thermomenter \& } \\
\text { liquid crystal workshop }\end{array}$ & $\begin{array}{l}25 \\
50 \\
25 \\
\end{array}$ & $\begin{array}{l}\text { undergrad } \\
\text { Children } \\
\text { HS student }\end{array}$ & $\begin{array}{l}\text { in report } \\
\text { in report } \\
\text { est by counting ppl in pics }\end{array}$ \\
\hline Koç Univ. & $\begin{array}{l}\text { Solar Race } \\
\text { Science Festivals for Kids }\end{array}$ & $\begin{array}{l}24 \\
10\end{array}$ & $\begin{array}{l}\text { children/HS } \\
\text { Children }\end{array}$ & $\begin{array}{l}\text { in report } \\
\text { est by counting ppl in pics }\end{array}$ \\
\hline $\begin{array}{l}\text { Samara State } \\
\text { Univ. }\end{array}$ & $\begin{array}{l}\text { "excusrions and review } \\
\text { lectures for schoolchildren } \\
\text { and students in Samara } \\
\text { Branch of the Lebedev } \\
\text { physical Institute." }\end{array}$ & $?$ & children/HS & unknown \\
\hline Silesian & $\begin{array}{l}\text { Demonstrations of physical } \\
\text { and optical experiments }\end{array}$ & 30 & children/HS & est by counting ppl in pics \\
\hline $\begin{array}{l}\text { St. Petersburg } \\
\text { ITMO }\end{array}$ & $\begin{array}{l}\text { Scientific Youth School } \\
\text { "Optics - 2006" }\end{array}$ & & & unknown \\
\hline U Alberta & $\begin{array}{l}\text { SPIE Info Lunch } \\
\text { Engineering Open House } \\
\text { (Laser Maze to return in } \\
\text { 2007) }\end{array}$ & $\begin{array}{l}50 \\
40\end{array}$ & $\begin{array}{l}\text { undergrad } \\
\text { HS student }\end{array}$ & $\begin{array}{l}\text { in report } \\
\text { (estimated) }\end{array}$ \\
\hline Wroclaw & $\begin{array}{l}\text { "Festival of Science" } \\
\text { "Magic of Physics" }\end{array}$ & $\begin{array}{c}250 \\
75 \\
\end{array}$ & $\begin{array}{l}\text { HS student } \\
\text { Children }\end{array}$ & $\begin{array}{l}\text { (estimated) } \\
\text { (estimated) }\end{array}$ \\
\hline $\begin{array}{l}\text { Nicolas } \\
\text { Copernicus }\end{array}$ & $\begin{array}{l}\text { Junior High School } \\
\text { Presentation } \\
\text { "Electric and Magnetic Field" }\end{array}$ & 350 & Children & est by counting ppl in pics \\
\hline Warsaw & Festival of Science & 250 & HS student & (estimated) \\
\hline INAOE & $\begin{array}{l}\text { Science workshop for HS } \\
\text { students } \\
\text { "Taller de Ciencia para } \\
\text { jovenes" } \\
\text { Science workshop for } \\
\text { children } \\
\text { "Baños de ciencia con el } \\
\text { GTM" } \\
\text { GTM = Gran Telescopio } \\
\text { Milimetrico }\end{array}$ & 120 & Children & est by counting ppl in pics \\
\hline
\end{tabular}




\begin{tabular}{|c|c|c|c|c|}
\hline & $\begin{array}{l}\text { 13th national Week of } \\
\text { Science and Technology } \\
\text { Children's workshops } \\
\text { 13th national Week of } \\
\text { Science and Technology } \\
\text { Matlab workshop } \\
\text { 13th national Week of } \\
\text { Science and Technology } \\
\text { Presentation: Optics at the } \\
\text { INAOE } \\
\text { 8th International Festival of } \\
\text { Puebla } \\
\text { Reading \& Science } \\
\text { workshop } \\
\text { "Baños de ciencia" at } \\
\text { "Consejo puebla de lectura" }\end{array}$ & $\begin{array}{l}15 \\
15 \\
\end{array}$ & $\begin{array}{l}\text { Children } \\
\text { HS / Univ } \\
\text { students }\end{array}$ & $\begin{array}{l}\text { est by counting ppl in pics } \\
\text { est by counting ppl in pics } \\
\text { est by counting ppl in pics }\end{array}$ \\
\hline UC Davis & $\begin{array}{l}\text { "Preview Day" - HS students } \\
\text { visit the University } \\
\text { Outreach events: Feb } 25, \\
\text { April } 8,16,16 \text {, and } 27 . \\
\text { Lazer Maze }\end{array}$ & $\begin{array}{c}? \\
? \\
500 \\
\end{array}$ & $\begin{array}{l}\text { HS student } \\
\text { Children } \\
\text { Children }\end{array}$ & $\begin{array}{l}\text { unknown } \\
\text { unknown } \\
\text { on website (reported) }\end{array}$ \\
\hline Univ. of Dayton & $\begin{array}{l}\text { Outreach at Miamisburgh } \\
\text { High School } \\
\text { Grade } 10 \text { outreach in } \\
\text { conjunction with Air Force } \\
\text { Research Laboratory }\end{array}$ & $?$ & $\begin{array}{l}\text { HS student } \\
\text { HS student }\end{array}$ & $\begin{array}{l}\text { unknown } \\
\text { unknown }\end{array}$ \\
\hline $\begin{array}{l}\text { Montréal } \\
\text { Chapter }\end{array}$ & 2 Day Optics workshop & 37 & $\begin{array}{l}\text { undergrad \& } \\
\text { grad }\end{array}$ & in report \\
\hline $\mathrm{ClO}$ & $\begin{array}{l}\text { Hands-on Workshops for } \\
\text { teachers } \\
\text { Science Club for Children ( } 4 \\
\text { meetings thus far) } \\
\text { Science club participation } \\
\text { (for Children and Teens) }\end{array}$ & $?$ & $\begin{array}{l}\text { Teachers } \\
\text { Children }\end{array}$ & $\begin{array}{l}\text { unknown } \\
\text { est by counting ppl in pics }\end{array}$ \\
\hline Notre Dame & $\begin{array}{l}\text { Academic seminars (invited } \\
\text { speaker for students and } \\
\text { faculty) }\end{array}$ & 30 & $\begin{array}{l}\text { under / grad / } \\
\text { prof }\end{array}$ & in report \\
\hline MEPhl & $\begin{array}{l}\text { Alex Radnaev's visit to } \\
\text { Irkutsk State Univ (ISU) }\end{array}$ & 10 & $\begin{array}{l}\text { under / grad / } \\
\text { prof }\end{array}$ & unknown \\
\hline Alabama A\&M & $\begin{array}{l}\text { Nobel Laureate Lecture: } \\
\text { Frank Wilczek } \\
\text { "Senior Day": Physics Demo } \\
\text { \& Physics Skit }\end{array}$ & $\begin{array}{c}300 \\
? \\
\end{array}$ & $\begin{array}{l}\text { under / grad / } \\
\text { prof }\end{array}$ & $\begin{array}{l}\text { in report } \\
\text { unknown }\end{array}$ \\
\hline Kent State Univ. & Boy Scouts at Kent State! & 12 & Children & est by counting ppl in pics \\
\hline
\end{tabular}

Total: $\quad 2823$ 
2007 Chapter Outreach Activities

\begin{tabular}{|c|c|c|c|c|}
\hline Chapter & Activity & $\begin{array}{l}\text { \# people } \\
\text { reached }\end{array}$ & Type & Counted (how)? \\
\hline CUSAT & $\begin{array}{l}\text { 10-day Workshop for } \\
\text { Children }\end{array}$ & 30 & High School & est. by counting ppl in pics \\
\hline \multirow[t]{3}{*}{$\begin{array}{l}\text { Ctr. de } \\
\text { Investigaciones } \\
\text { en Óptica - Leon }\end{array}$} & $\begin{array}{l}\text { Hands-on Workshop for } \\
\text { Students }\end{array}$ & 60 & High School & in report \\
\hline & Science Club for Children & 108 & Children & est. by counting ppl in pics \\
\hline & Visits to High Schools & 29 & $\begin{array}{l}\text { High School, } \\
\text { Elementary }\end{array}$ & est. by counting ppl in pics \\
\hline Duke University & $\begin{array}{l}\text { Wetherstone Elementary } \\
\text { Optics Demo day }\end{array}$ & 90 & Elm school & reported \\
\hline Duke University & $\begin{array}{l}\text { Career Day - North } \\
\text { Rayleigh Christian } \\
\text { Academy }\end{array}$ & $50-75$ & $\begin{array}{l}\text { Middle+High } \\
\text { School }\end{array}$ & reported/guess \\
\hline IUP & High School Outreach & 21 & High School & est. by counting ppl in pics \\
\hline \multirow[t]{2}{*}{$\begin{array}{l}\text { Univ. of } \\
\text { Alabama }\end{array}$} & High School Outreach & 200 & High School & est. by counting ppl in pics \\
\hline & $\begin{array}{l}\text { Elementary School } \\
\text { Outreach }\end{array}$ & 5 & $\begin{array}{l}\text { Elementary } \\
\text { school }\end{array}$ & est. by counting ppl in pics \\
\hline \multirow[t]{2}{*}{ Univ. of Dayton } & Miami Valley TechFest & 18 & $\begin{array}{l}\text { Elementary } \\
\text { school }\end{array}$ & est. by counting ppl in pics \\
\hline & Optics Demos & 14 & High School & est. by counting ppl in pics \\
\hline \multirow[t]{2}{*}{$\begin{array}{l}\text { Univ. of New } \\
\text { Mexico }\end{array}$} & $\begin{array}{l}\text { Central NM Science \& } \\
\text { Engineering Research } \\
\text { Challenge }\end{array}$ & 500 & $\begin{array}{l}\text { Elementary - } \\
\text { High School }\end{array}$ & in report \\
\hline & Intel Science Fair & 30 & High School & in report, 1500 attendees \\
\hline \multirow[t]{2}{*}{$\begin{array}{l}\text { Vrije Universiteit } \\
\text { Brussel }\end{array}$} & $\begin{array}{l}\text { Fascination w/Light } \\
\text { Exhibition }\end{array}$ & 1000 & $\begin{array}{l}\text { Elementary- } \\
\text { High School }\end{array}$ & in report \\
\hline & Edukit Training & 7 & $\begin{array}{l}\text { High School } \\
\text { Teachers }\end{array}$ & est. by counting ppl in pics \\
\hline $\begin{array}{l}\text { Warsaw Univ. of } \\
\text { Technology }\end{array}$ & $\begin{array}{l}\text { Optics Workshops for } \\
\text { Children }\end{array}$ & 100 & $\mathrm{~K}-12$ & in report \\
\hline \multirow[t]{2}{*}{ Wroclaw Univ. } & $\begin{array}{l}\text { Magic of Physics } \\
\text { Presentation }\end{array}$ & 36 & $\begin{array}{l}\text { Elementary } \\
\text { school }\end{array}$ & est. by counting ppl in pics \\
\hline & Liquid Crystals Presentation & 13 & High School & est. by counting ppl in pics \\
\hline \multirow[t]{2}{*}{$\begin{array}{l}\text { Ctr. de } \\
\text { Investigaciones } \\
\text { en Óptica - Leon }\end{array}$} & $\begin{array}{l}\text { Hands-on Workshop for } \\
\text { Students }\end{array}$ & 65 & High School & in report \\
\hline & Science Club for Children & 12 & Children & est. by counting ppl in pics \\
\hline
\end{tabular}




\begin{tabular}{|c|c|c|c|c|}
\hline $\begin{array}{l}\text { Delhi College of } \\
\text { Engg }\end{array}$ & $\begin{array}{l}\text { Lecture for High School } \\
\text { Students: Optics and The } \\
\text { Internet }\end{array}$ & 5 & High School & est. by counting ppl in pics. \\
\hline INAOE & $\begin{array}{l}\text { Seminar in honor of the } \\
\text { National Week of Science } \\
\text { and Technology }\end{array}$ & 150 & high school & in report \\
\hline PUCP & $\begin{array}{l}\text { Workshop on Optics for } \\
\text { High School Teachers }\end{array}$ & 20 & $\begin{array}{l}\text { High school } \\
\text { Instructors }\end{array}$ & in report \\
\hline UNC Charlotte & $\begin{array}{l}\text { Nobel Laureate Visits UNC } \\
\text { Charlotte/Outreach } \\
\text { Activities }\end{array}$ & 250 & High school & in report \\
\hline \multirow[t]{2}{*}{ ISP } & Optics Fair & 1200 & $\begin{array}{l}\text { Middle School, } \\
\text { High School }\end{array}$ & in report \\
\hline & Optics to School & 71 & $\begin{array}{l}\text { Middle School, } \\
\text { High School }\end{array}$ & $\begin{array}{l}\text { est. by counting ppl in pics } \\
\text { on website of event }\end{array}$ \\
\hline \multirow[t]{2}{*}{ Koc Univ } & Solar Boat Race & 15 & High School & $\begin{array}{l}\text { est. by counting ppl in pics } \\
\text { on website of event }\end{array}$ \\
\hline & Solar Car Race & 28 & High School & $\begin{array}{l}\text { est. by counting ppl in pics } \\
\text { on website of event }\end{array}$ \\
\hline \multirow[t]{3}{*}{ Lehigh Univ } & $\begin{array}{l}\text { Lab Tour for Local Cub } \\
\text { Scouts }\end{array}$ & 5 & Children & est. by counting ppl in pics \\
\hline & COT OPTO Camp & 12 & Middle School & in report \\
\hline & $\begin{array}{l}\text { Local Middle School Optics } \\
\text { Demo }\end{array}$ & 75 & Middle School & in report \\
\hline NITT & $\begin{array}{l}\text { Assisting local students } \\
\text { w/computer knowledge }\end{array}$ & 34 & $\begin{array}{l}\text { Middle School, } \\
\text { High School }\end{array}$ & est. by counting ppl in pics \\
\hline $\begin{array}{l}\text { Silesian Univ. of } \\
\text { Techn }\end{array}$ & $\begin{array}{l}\text { Demos for High School } \\
\text { Students }\end{array}$ & 10 & High School & est. by counting ppl in pics. \\
\hline \multirow[t]{2}{*}{ Stanford } & Science Educator's Day & 75 & (K-12 teachers) & in report \\
\hline & $\begin{array}{l}\text { Community Day Science } \\
\text { Demo Booths }\end{array}$ & 198 & Children & est. by counting ppl in pics \\
\hline Taurida & Optics Demos in Classroom & 36 & $5-9$ yrs old & est, by counting ppl in pics \\
\hline \multirow[t]{3}{*}{$\begin{array}{l}\text { Univ. of Calcutta } \\
\text { Chapter }\end{array}$} & $\begin{array}{l}\text { Outreach at Loreta Day } \\
\text { School }\end{array}$ & 140 & Children & in report \\
\hline & $\begin{array}{l}\text { Outreach at Our Lady } \\
\text { Queen of Missions School }\end{array}$ & 150 & Children & in report \\
\hline & Outreach at Svarna School & 50 & Children & in report \\
\hline UCSD & Holography Workshop & 24 & Middle School & in report \\
\hline $\begin{array}{l}\text { Univ. of New } \\
\text { Mexico }\end{array}$ & $\begin{array}{l}\text { organized high school SPIE } \\
\text { chapter }\end{array}$ & 12 & High School & in report \\
\hline Wroclaw Univ. & Festival of Science & 25 & $\mathrm{~K}-12$ & est. by counting ppl in pics \\
\hline
\end{tabular}




\begin{tabular}{|l|l|l|l|l|} 
& $\begin{array}{l}\text { Magic of Physics } \\
\text { Presentation (for } \\
\text { Elementary School } \\
\text { Children) }\end{array}$ & $?$ & $\begin{array}{l}\text { Elementary } \\
\text { School }\end{array}$ & unknown \\
\hline & Liquid Crystals Presentation & 24 & High School & est. by counting ppl in pics \\
\hline & $\begin{array}{l}\text { MFI (Math/Science } \\
\text { Tutorials) }\end{array}$ & $?$ & $\begin{array}{l}\text { Hecording to report, } 10 \text { high } \\
\text { schools took part, but I don't } \\
\text { know how this translates } \\
\text { numerically }\end{array}$ \\
\hline
\end{tabular}

Total: $\quad 4947$

Proc. of SPIE Vol. $966696660 \mathrm{~A}-16$ 
2008 Chapter Outreach

\begin{tabular}{|c|c|c|c|c|}
\hline Chapter & Activity & $\begin{array}{l}\text { \# people } \\
\text { reached }\end{array}$ & Type & Counted (how)? \\
\hline Chulalongkorn & Science Fair & 600 & & reported via email \\
\hline $\begin{array}{l}\text { Ctr. de } \\
\text { Investigaciones } \\
\text { en Óptica - } \\
\text { Leon }\end{array}$ & $\begin{array}{l}\text { Science Club for } \\
\text { Children }\end{array}$ & 146 & $\mathrm{~K}-12$ & $\begin{array}{l}\text { est. by counting ppl in } \\
\text { pics }\end{array}$ \\
\hline CUSAT & $\begin{array}{l}\text { 10-day Workshop for } \\
\text { Children }\end{array}$ & 33 & High School & $\begin{array}{l}\text { est. by counting ppl in } \\
\text { pics }\end{array}$ \\
\hline \multirow[t]{3}{*}{ INAOE } & $\begin{array}{l}\text { Periscope Workshop } \\
\text { during learning fair/univ. } \\
\text { anniversary }\end{array}$ & 1000 & Children & in report \\
\hline & $\begin{array}{l}\text { Kaleidoscope Workshop } \\
\text { during learning fair/univ. } \\
\text { anniversary }\end{array}$ & 900 & Children & in report \\
\hline & $\begin{array}{l}\text { Total Moon Eclipse } \\
\text { Telescope Outreach }\end{array}$ & 320 & $\begin{array}{l}\text { (people under } \\
15 \text { ) }\end{array}$ & $\begin{array}{l}\text { in report/estimated. (See } \\
\text { note for how) }\end{array}$ \\
\hline ISP & Optics Fair & 1400 & $\mathrm{~K}-12$ & in report \\
\hline Ivan Franko & $\begin{array}{l}\text { Amazing Optics } \\
\text { Presentation }\end{array}$ & 28 & 1rst grade & $\begin{array}{l}\text { est. by counting ppl in } \\
\text { pics }\end{array}$ \\
\hline Latvia & Night of Science & 700 & $\mathrm{~K}-12 ?$ & reported via email \\
\hline Lehigh & Optics Presentations & 52 & Middle School & in report \\
\hline Lomonosov & $\begin{array}{l}\text { Moscow Science } \\
\text { Festival }\end{array}$ & 50 & High School & in report \\
\hline Montana State & High School Visit & 30 & High School & reported via email \\
\hline \multirow[t]{2}{*}{$\begin{array}{l}\text { Montreal } \\
\text { Chapter }\end{array}$} & $\begin{array}{l}\text { Electromagnetism and } \\
\text { Optics Presentations }\end{array}$ & 110 & High School & reported via email \\
\hline & $\begin{array}{l}\text { Electromagnetism and } \\
\text { Optics Presentations }\end{array}$ & 85 & High School & reported via email \\
\hline \multirow[t]{2}{*}{$\begin{array}{l}\text { Nicholas } \\
\text { Copernicus } \\
\text { University }\end{array}$} & $\begin{array}{l}\text { Lab visits by Krakow } \\
\text { high schools }\end{array}$ & $?$ & High School & unknown \\
\hline & $\begin{array}{l}\text { Festival of Art and } \\
\text { Science Workshops }\end{array}$ & 1000 & $\begin{array}{l}\text { children, } \\
\text { middle, high } \\
\text { school }\end{array}$ & in report \\
\hline NITT & $\begin{array}{l}\text { Awareness Program on } \\
\text { Physics Ed \& Res. '08 }\end{array}$ & 100 & college level & in report \\
\hline \multirow[t]{3}{*}{ Penn State } & $\begin{array}{l}\text { Electrical Engineering } \\
\text { Open House }\end{array}$ & 200 & High School & in report \\
\hline & $\begin{array}{l}\text { Nittany Valley Charter } \\
\text { School Outreach }\end{array}$ & 21 & $\begin{array}{l}\text { elementary, } \\
\text { middle school }\end{array}$ & $\begin{array}{l}\text { est. by counting ppl in } \\
\text { pics }\end{array}$ \\
\hline & $\begin{array}{l}\text { Kelly Elementary } \\
\text { School Outreach }\end{array}$ & 16 & elementary & in report \\
\hline
\end{tabular}




\begin{tabular}{|c|c|c|c|c|}
\hline & $\begin{array}{l}\text { WISE (Women in } \\
\text { Science \& Engineering) } \\
\text { Summer Camp } \\
\text { Demo/Workshop }\end{array}$ & 16 & High School & $\begin{array}{l}\text { based on WISE website's } \\
\text { description of how many } \\
\text { students are generally in } \\
\text { a workshop }\end{array}$ \\
\hline PUCP & $\begin{array}{l}\text { Basic Optics } \\
\text { Presentation at all-girls } \\
\text { school }\end{array}$ & 50 & High School & $\begin{array}{l}\text { est. by counting ppl in } \\
\text { pics }\end{array}$ \\
\hline \multirow[t]{2}{*}{$\begin{array}{l}\text { Silesian Univ. of } \\
\text { Tech. }\end{array}$} & Science Festival & 100 & High School & reported via email \\
\hline & Lecture on LCD & 50 & High School & reported via email \\
\hline \multirow[t]{2}{*}{ Stanford } & $\begin{array}{l}\text { Girls Scouts Go Tech } \\
2008\end{array}$ & 100 & $\begin{array}{l}\text { elementary } \\
\text { school }\end{array}$ & in report \\
\hline & $\begin{array}{l}\text { Optics-themed } \\
\text { Photography Contest }\end{array}$ & 50 & 6th-12th grade & on website \\
\hline \multirow[t]{2}{*}{$\begin{array}{l}\text { Tec de } \\
\text { Monterrey }\end{array}$} & $\begin{array}{l}\text { Terrific Telescopes - } \\
\text { used Hands On Optics } \\
\text { Kits }\end{array}$ & 38 & $\mathrm{~K}-10$ & in report \\
\hline & $\begin{array}{l}\text { Liquid Crystals/"Mood } \\
\text { Patch" Outreach }\end{array}$ & 110 & $\mathrm{~K}-12$ & in report \\
\hline \multirow[t]{3}{*}{$\begin{array}{l}\text { Three Rivers } \\
\text { Comm. College }\end{array}$} & $\begin{array}{l}\text { Demos on } \\
\text { Phosphoresence, } \\
\text { Luminescence \& } \\
\text { building telescopes }\end{array}$ & 75 & 5th grade & in report \\
\hline & Laser Camp '08 & 30 & High School & in report \\
\hline & $\begin{array}{l}\text { UV demo at Read } \\
\text { Across America }\end{array}$ & $?$ & Children & unknown \\
\hline CUVO & Workshop on Optics & 43 & age 8-13 & $\begin{array}{l}\text { est. by counting ppl in } \\
\text { pics }\end{array}$ \\
\hline UC Berkeley & Girls Science Workship & 25 & Middle School & in report \\
\hline \multirow[t]{2}{*}{ Univ. Laval } & $\begin{array}{l}\text { Girls in Science } \\
\text { Workshop on Optics }\end{array}$ & 12 & High School & in report \\
\hline & Jeux Photoniques & 55 & High School & reported via email \\
\hline \multirow[t]{2}{*}{ Univ. of Arizona } & Science Fair Judging & $?$ & $\mathrm{~K}-12$ & unknown \\
\hline & Optical Sciences Camp & 18 & High School & in report \\
\hline \multirow[t]{3}{*}{$\begin{array}{l}\text { Univ. of } \\
\text { Calcutta }\end{array}$} & $\begin{array}{l}\text { Outreach Activity at } \\
\text { Vidyasagar Study } \\
\text { Centre }\end{array}$ & 86 & $\begin{array}{l}\text { Middle } \\
\text { School? }\end{array}$ & in report \\
\hline & $\begin{array}{l}\text { Scientific } \\
\text { Demonstrations }\end{array}$ & 415 & $\begin{array}{l}\text { Middle School, } \\
\text { High School }\end{array}$ & in report \\
\hline & Optics Kits Demos & 264 & High School & in report \\
\hline \multirow[t]{3}{*}{ CREOL } & $\begin{array}{l}\text { Expanding Your } \\
\text { Horizons in Science \& } \\
\text { Math (for girls) }\end{array}$ & 200 & Middle School & on website \\
\hline & Optics Day & 300 & misc. ages & on website \\
\hline & $\begin{array}{l}\text { Super Scientists at } \\
\text { Partin Elementary }\end{array}$ & ? & $\begin{array}{l}\text { elementary } \\
\text { school }\end{array}$ & unknown \\
\hline
\end{tabular}




\begin{tabular}{|c|c|c|c|c|}
\hline & Lab Tours & $\begin{array}{c}\text { ? - site } \\
\text { says } \\
\text { hundreds }\end{array}$ & $\begin{array}{l}\text { Middle School, } \\
\text { High School }\end{array}$ & unknown \\
\hline Univ. Dayton & Optics Demo & 10 & High School & $\begin{array}{l}\text { est. by counting ppl in } \\
\text { pics }\end{array}$ \\
\hline $\begin{array}{l}\text { Univ. of } \\
\text { Guanajuato }\end{array}$ & $\begin{array}{l}\text { Children in Science } \\
\text { Academy }\end{array}$ & 15 & $\begin{array}{l}\text { elementary } \\
\text { school }\end{array}$ & $\begin{array}{l}\text { est. by counting ppl in } \\
\text { pics }\end{array}$ \\
\hline \multirow[t]{2}{*}{$\begin{array}{l}\text { Univ. New } \\
\text { Mexico }\end{array}$} & $\begin{array}{l}\text { West Mesa Chapter Lab } \\
\text { Tour }\end{array}$ & 10 & High School & in report \\
\hline & $\begin{array}{l}\text { Hands-on-Optics Kit } \\
\text { Outreach at Kit Carson } \\
\text { Middle School }\end{array}$ & 60 & Middle School & reported via email \\
\hline \multirow[t]{2}{*}{ UNC Charlotte } & Outreach Tour & 15 & High School & in report \\
\hline & Girl Scouts visit & 20 & Elementary & in report \\
\hline \multirow[t]{2}{*}{ Wroclaw } & Festival of Science & 50 & Elementary & in report \\
\hline & Magic of Physics & 18 & High School & $\begin{array}{l}\text { est. by counting ppl in } \\
\text { pics }\end{array}$ \\
\hline Yerevan & Physics Olympiad & 16 & High School & reported via email \\
\hline \multirow[t]{2}{*}{$\begin{array}{l}\text { Vrije Univ. } \\
\text { Brussel }\end{array}$} & $\begin{array}{l}\text { Distributed Edukits (free } \\
\text { educational optics kits) }\end{array}$ & 1,000 & misc. ages & in report \\
\hline & $\begin{array}{l}\text { Photonics Science } \\
\text { Show }\end{array}$ & 630 & High School & in report \\
\hline \multirow[t]{2}{*}{ Duke Univ. } & $\begin{array}{l}\text { Optics Demonstrations } \\
\text { and Presentation }\end{array}$ & 30 & Middle School & in report \\
\hline & Outreach Visit & 25 & Middle School & $\begin{array}{l}\text { est. by counting ppl in } \\
\text { pics }\end{array}$ \\
\hline \multirow[t]{4}{*}{ INAOE } & $\begin{array}{l}\text { Week of Life and } \\
\text { Science }\end{array}$ & 240 & $\begin{array}{l}\text { Middle and } \\
\text { High School }\end{array}$ & in report \\
\hline & $\begin{array}{l}\text { INAOE talks / } \\
\text { workshops with } \\
\text { students ( } 16 \text { total) }\end{array}$ & 710 & $\begin{array}{l}\text { Middle and } \\
\text { High School }\end{array}$ & in report \\
\hline & $\begin{array}{l}\text { Week of Science and } \\
\text { Technology }\end{array}$ & 380 & misc. ages & in report \\
\hline & $\begin{array}{l}\text { Week of Science in } \\
\text { High School }\end{array}$ & 60 & High School & in report \\
\hline $\begin{array}{l}\text { Nizhny } \\
\text { Novgorod }\end{array}$ & $\begin{array}{l}\text { Developing video to } \\
\text { explain basics of } \\
\text { Edukits for high school } \\
\text { teachers and students }\end{array}$ & ??? & High School & unknown \\
\hline \multirow[t]{2}{*}{$\begin{array}{l}\text { Taras } \\
\text { Shevchenko } \\
\text { National Univ. } \\
\text { of Kyiv }\end{array}$} & $\begin{array}{l}\text { Invited high school } \\
\text { students to exhibit and } \\
\text { plenary session of } \\
\text { Young Scientists } \\
\text { conference }\end{array}$ & ??? & High School & unknown \\
\hline & $\begin{array}{l}\text { Tutoring middle and } \\
\text { high school students in } \\
\text { physics and math one } \\
\text { day a week }\end{array}$ & ??? & $\begin{array}{l}\text { Middle and } \\
\text { High School }\end{array}$ & Unknown \\
\hline
\end{tabular}




\begin{tabular}{|l|l|c|l|l|} 
UCSD - Triton & Holography Workshop & 60 & High School & in report \\
\hline UNC Charlotte & Girl Scouts visit & $? ? ?$ & Elementary & Unknown \\
\hline $\begin{array}{l}\text { Univ. of Texas } \\
\text { at Austin }\end{array}$ & $\begin{array}{l}\text { "Fun with Optics" } \\
\text { program, part of Explore } \\
\text { UT open house }\end{array}$ & 150 & misc. ages & in report \\
\hline $\begin{array}{l}\text { Warsaw Univ. of } \\
\text { Technology }\end{array}$ & Festival of Science & 100 & $\begin{array}{l}\text { elementary } \\
\text { school }\end{array}$ & in report \\
\hline & Workshops for Children & $?$ & children & unknown \\
\hline
\end{tabular}

Total:

11827

Proc. of SPIE Vol. 9666 96660A-20 